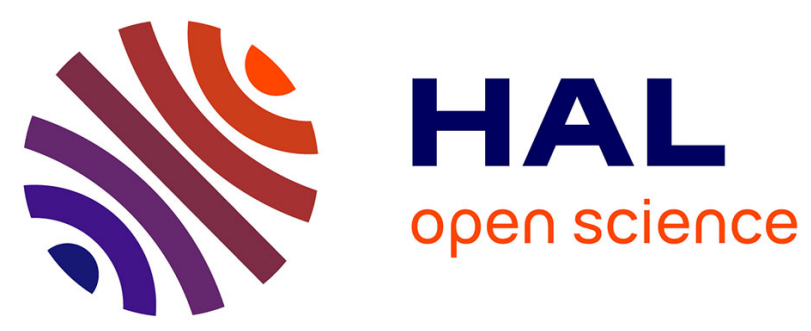

\title{
High matrix interference affecting detection of PAH metabolites in bile of Atlantic hagfish () used for biomonitoring of deep-water oil production
}

Rolf C. Sundt, Jonny Beyer, Sjur Vingen, Magne O. Sydnes

\section{- To cite this version:}

Rolf C. Sundt, Jonny Beyer, Sjur Vingen, Magne O. Sydnes. High matrix interference affecting detection of PAH metabolites in bile of Atlantic hagfish () used for biomonitoring of deep-water oil production. Marine Environmental Research, 2011, 10.1016/j.marenvres.2011.04.006 . hal-00703484

\author{
HAL Id: hal-00703484 \\ https://hal.science/hal-00703484
}

Submitted on 2 Jun 2012

HAL is a multi-disciplinary open access archive for the deposit and dissemination of scientific research documents, whether they are published or not. The documents may come from teaching and research institutions in France or abroad, or from public or private research centers.
L'archive ouverte pluridisciplinaire HAL, est destinée au dépôt et à la diffusion de documents scientifiques de niveau recherche, publiés ou non, émanant des établissements d'enseignement et de recherche français ou étrangers, des laboratoires publics ou privés. 


\section{Accepted Manuscript}

Title: High matrix interference affecting detection of PAH metabolites in bile of Atlantic hagfish (Myxine glutinosa) used for biomonitoring of deep-water oil production

Authors: Rolf C. Sundt, Jonny Beyer, Sjur Vingen, Magne O. Sydnes

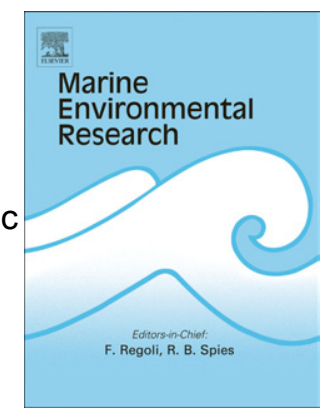

PII:

S0141-1136(11)00049-3

DOI:

10.1016/j.marenvres.2011.04.006

Reference: MERE 3522

To appear in: Marine Environmental Research

Received Date: 11 February 2011

Revised Date: 19 April 2011

Accepted Date: 25 April 2011

Please cite this article as: Sundt, R.C., Beyer, J., Vingen, S., Sydnes, M.O. High matrix interference affecting detection of PAH metabolites in bile of Atlantic hagfish (Myxine glutinosa) used for biomonitoring of deep-water oil production, Marine Environmental Research (2011), doi: 10.1016/ j.marenvres.2011.04.006

This is a PDF file of an unedited manuscript that has been accepted for publication. As a service to our customers we are providing this early version of the manuscript. The manuscript will undergo copyediting, typesetting, and review of the resulting proof before it is published in its final form. Please note that during the production process errors may be discovered which could affect the content, and all legal disclaimers that apply to the journal pertain. 
High matrix interference affecting detection of PAH metabolites in bile of Atlantic hagfish (Myxine glutinosa) used for biomonitoring of deep-water oil production.

Rolf C. Sundt ${ }^{\text {a }}$, Jonny Beyer ${ }^{\text {a,b }}$, Sjur Vingen ${ }^{\text {a }}$ and Magne O. Sydnes ${ }^{a_{*}}$

a IRIS - International Research Institute of Stavanger, P.O. Box 8046, N-4068,

Stavanger, Norway

${ }^{b}$ University of Stavanger, N-4036 Stavanger, Norway

* Corresponding author:

Magne O. Sydnes, International Research Institute of Stavanger, P.O. Box 8046, N4068, Stavanger, Norway

Tel +4751875566

Fax +47 51875540

e-mail: magne.olav.sydnes@iris.no

Running head: bile fluorescence in hagfish

Key-words: Atlantic hagfish, Myxine glutinosa, bile fluorescence, PAH, biomonitoring, Barents Sea 


\section{Abstract}

The characteristic biology and wide distribution of hagfish species makes them relevant for use in pollution biomonitoring at great water depths, particularly in regions where deep-water oil exploration may take place. The exposure of fish to petrogenic contaminants can normally be detected from the level of polycyclic aromatic hydrocarbon (PAH) metabolites in bile fluid. Some of these metabolites are strong fluorophores, allowing analytical detection by means of simple fluorometric techniques such as fixed wavelength fluorescence (FF) and synchronous fluorescence scanning (SFS). In the present study bile from Atlantic hagfish (Myxine glutinosa) collected in pristine areas (Barents Sea and southwestern Norway) displayed strong bile fluorescence levels, suggesting the presence of PAH contaminants. However, gaschromatography-mass spectrometry (GC-MS) analyses ruled out PAHs as the origin for this fluorescence signal. Rather, the bile of Myxine contains components resulting in unusually strong background fluorescence interfering at the wavelength pairs used for detection of PAH metabolites. Possible background for the observed matrix interference and implications for detection of PAH metabolites in hagfish is discussed.

\section{Introduction}

The current increase in exploitation of deep-water hydrocarbon resources brings along the need for target study species for biomonitoring surveys. Due to the generally low species diversity and density of populations at great depths, selecting suitable sentinel species may be challenging. Several aspects of hagfish biology make the species potentially suitable for such purposes. The availability of Atlantic hagfish (Myxine glutinosa) is generally good as it can be caught with baited traps. The distribution range is wide and it can be found on both sides of the Atlantic Ocean at depths from 20-1100 $\mathrm{m}$ (Collette and Klein-McPhee, 2002). The potential for migratory movement is moderate, but the fact that hagfish are scavenging on carcasses of long lived species may expose hagfish to pollutants acquired by the prey in a wide area reflecting a regional pollution signal rather than that at a specific collection site. Furthermore, their burrowing behavior may increase the uptake of pollutants associated to the sediment, such as PAHs, through cutaneous absorption. 
The presence of hagfish cytochrome P450 (CYP1A) genes and functional CYP1A enzymes (Andersson and Nilsson, 1989) or CYP1A homologues (Hahn et al., 1998) makes hagfish capable of metabolizing PAHs, although the CYP1A is not aryl hydrocarbon receptor (AHR) regulated (Hahn, 2002). Bile fluid of Atlantic hagfish should therefore contain detectable concentrations of PAH metabolites following exposure to these chemicals. The concentration of PAH metabolites in bile is a commonly used method to determine the level of exposure to petrogenic contaminants (Beyer et al., 2010). Bile fluorescence measured by fixed wavelength fluorescence (FF) has been useful for many fish species providing semi quantitative measures of PAH metabolites present in the bile of these species (Krahn et al., 1987; Aas and Klungsøyr, 1998; Beyer et al., 1998; van de oost et al. 2003; Insausti et al., 2009). A subset of samples from FF analysis is often subjected to GC-MS analysis in order to confirm the FF results and accurately determine the concentration of the various PAH metabolites in the bile. Experience from several research groups has led to the following recommended excitation/emission (ex/em) wavelength pairs: 290/335 nm for 2/3-ring PAH metabolites (e.g. naphthalene and phenanthrene), 341/383 nm for 4-ring PAH metabolites (e.g. pyrene), and 380/430 nm for 5/6-ring PAH metabolites (e.g. benzo[a]pyrene) (Krahn et al., 1984; Krahn et al., 1987; Lin et al., 1996; Aas et al., 1998; Aas et al., 2000; Ariese et al., 2005; Beyer et al., 2010).

As part of a baseline study prior to production start-up at the offshore oilfield Goliat in the Southern Barents Sea (Figure 1), the potential utility of Atlantic hagfish as a sentinel species in biomonitoring of petrogenic contamination was evaluated. Other fish species collected at the site displayed a low bile fluorescence signals typical for pristine areas, however, fluorescence signals from hagfish bile were unexpectedly high. In order to better understand the basis for this observation, additional Atlantic hagfish were collected in southwestern (SW) Norway. A group of this fish was exposed to $0.25 \mathrm{ppm}$ dispersed crude oil for a week in order to investigate bile fluorescence responses to PAH exposure. 


\section{Materials and methods}

\subsection{Fish collection}

Atlantic hagfish were collected in the Southern Barents Sea $\left(71^{\circ} 16^{`} \mathrm{~N}, 22^{\circ} 06^{\circ} \mathrm{E}\right)$ at approximately 290 meters depth (22 individuals, average length $36 \mathrm{~cm}, \mathrm{SD}=3.4$ ) in October 2008, and in SW Norway (Åmøyfjord, 59 $01^{`} \mathrm{~N}, 05^{\circ} 44^{`} \mathrm{E}$ ) at approximately 100 meters depth (26 individuals, average length $26 \mathrm{~cm}, \mathrm{SD}=3.0$ ) in March 2009 (Figure 1). The hagfish were caught in traps made up from $150 \mathrm{~mm}$ perforated PE pipe with a $26 \mathrm{~mm}$ one-way funnel entrance. The entrance was fitted with splintered $1 \mathrm{~mm}$ plankton mesh to avoid animals escaping once inside the trap. Tusk (Brosme brosme) was collected at the same Barents Sea location using two-chamber traps (Furevik 1997). For both types of traps, frozen mackerel was used as bait.

$<<$ Insert Figure 1 >>

\subsection{Crude oil exposure}

Hagfish collected in SW Norway were used for this study. 11 Fish, average length 30 $\mathrm{cm}(\mathrm{SD}=2.6)$ were exposed for one week $\left(26^{\text {th }}\right.$ March to $2^{\text {nd }}$ April 2009) to $0.25 \mathrm{ppm}$ mechanically dispersed crude oil from the Goliat oil field in the Barents Sea. Parallel with the exposure of hagfish, halibut (Hippoglossus hippoglossus) originating from a local fish farm were identically exposed. The exposure setup is described in detail by Sanni et al. (1998). The control group for the exposure study consisted of 15 hagfish (average length $26 \mathrm{~cm}, \mathrm{SD}=3.0$ ). In order to document the exposure conditions, the size distribution of oil droplets in the control, exposure and header tank were monitored by Multisizer ${ }^{\mathrm{TM}}$ (Beckman Coulter) on day 7. In order to provide $\mathrm{PAH}$ profile and concentration information, a single water sample taken on day 5 of the exposure experiment was analysed by GC-MS for PAHs.

\subsection{Analyses}

\subsubsection{Fixed wavelength fluorescence (FF)}

Fixed wavelength fluorescence (FF) was conducted as described by Aas et al. (2001). Briefly, bile samples were diluted in 50\% methanol (1:1600) followed by measuring FF in a quartz cuvette on a Perkin Elmer LS50B luminescence spectrometer at 
excitation/emission (ex/em) wavelength pairs 290/335 nm, 341/383 nm, and 380/430 $\mathrm{nm}$. A slit width of $2.5 \mathrm{~nm}$ was used for both ex and em wavelengths.

\subsubsection{Mass spectrometric analyses}

Samples for mass spectrometric analysis of PAH metabolites in bile were prepared according to the method of Jonsson et al. (2003) and the analyses were run according to the method described by Jonsson et al. (2004). The extraction and analysis of PAHs in exposure water was performed as described by Jonsson et al. (2004). For this analysis, 2 L samples of seawater were extracted with cyclohexane. The analysis included quantitative determination of $16 \mathrm{PAH}$ species/species groups (Table 2).

\section{Results and discussion}

\subsection{Analysis of bile from Atlantic hagfish collected in the Barents Sea}

Samples of tusk collected at the Barents Sea site displayed low background bile fluorescence signals typical for pristine areas, however, fluorescence signals from hagfish bile were unexpectedly high (Figure 2). The high fluorescence levels observed in hagfish could incorrectly be interpreted and lead towards the conclusion that the analyzed specimens had high concentrations of PAH metabolites in bile. The data also show considerable variation of fluorescence profile among individual hagfish samples. This variability becomes clear when data from synchronous fluorescence spectrometry from selected samples is compared (Figure 3). Compared with the fluorescence levels obtained for tusk samples, which indicate normal background signals for fish collected in pristine waters, the levels measured in hagfish are approximately one order of magnitude higher (Figure 4).

<<Insert Figure 2〉>

$<<$ Insert Figure 3>>

<<Insert Figure 4>> 
The unusually high fluorescence levels and the individual variation in fluorescence profile prompted a more thorough investigation of the sample material. Bile from ten individual samples of Barents Sea hagfish were therefore subjected to GC-MS analysis. This analysis failed to confirm the presence of PAH metabolites included in the analysis, except $\mathrm{C}_{1}-\mathrm{OH}$-phenanthrene and $\mathrm{C}_{2}-\mathrm{OH}$-phenanthrene (Table 1). No typical petrogenic PAH metabolite profile was observed in the chromatogram window where peaks of $\mathrm{C}_{1}-\mathrm{OH}$-phenanthrene and $\mathrm{C}_{2}-\mathrm{OH}$-phenanthrene are normally observed. Instead, interference from other unknown compounds with slightly different retention times from the mentioned phenanthrene derivatives was observed. Signals from these compounds were dominating that region of the chromatogram preventing accurate quantification of the $\mathrm{C}_{1}-\mathrm{OH}$-phenanthrene and $\mathrm{C}_{2}-\mathrm{OH}$-phenanthrene levels in the samples.

$<<<$ Insert Table 1 $>$

$<<$ Insert Table 2>>

\subsection{Exposure experiments}

To better understand the matrix interference phenomenon, hagfish were collected in SW Norway. One group was exposed to $0.25 \mathrm{ppm}$ dispersed crude oil from the Goliat oil field and one group was kept in sea water only. The mean size of oil particles in the exposure water were $9.3 \mu \mathrm{m}$. Presence of PAHs in the exposure water was confirmed both by GC-MS analysis of water (Table 2) and by presence of metabolites in the halibut receiving the same water (Table 1).

Bile fluorescence in laboratory hagfish (hagfish collected in SW Norway) (both exposed and control) confirmed the high signals observed in the Barents Sea samples, although levels were slightly lower than what was observed for the hagfish kept in the laboratory. The individual differences were also less pronounced for the hagfish collected in SW Norway compared with the Barents Sea hagfish (Figure 4). The fluorescence levels in the hagfish were considerably higher than levels typically found in specimens of bony fish collected in pristine areas e.g. tusk collected at the Barents Sea site (Figure 4). Bile fluorescence in hagfish exposed to crude oil also showed individual variation in both level and profile. Another interesting finding was the low levels of PAH metabolites in bile from oil exposed hagfish compared to results from three individual bile samples 
from identically exposed halibut (Table 1). This indicates that the bioavailability of petrogenic PAHs in water is low for hagfish under the given laboratory conditions, or that it is not metabolized as efficiently.

\subsection{Uptake and excretion of PAHs in hagfish}

Currently little information is available regarding the biochemistry and metabolite formation in hagfish, although some studies have described the isolation of bile salts (Haslewood, 1966; Cross, 1966; Anderson et al., 1967; Haslewood, 1967; Anderson and Haslewood, 1969; Hofmann and Hagey, 2008) and antimicrobial peptides (Shinnar et al., 2003; Uzzel et al., 2003; Subramanian et al., 2009). Catalytically active CYP1A has been detected in Atlantic hagfish and is believed to contribute to the metabolism of some compounds in oil (Andersson and Nilsson, 1989; Hahn et al. 1998). The present laboratory exposure experiment indicates that the uptake of dispersed oil over the gill epithelium is significantly lower for hagfish than for halibut, or that aromatic compounds originating from the oil are not metabolized similarly to what occurs in other fish species (Table 1).

The low levels of PAH metabolites in bile of oil exposed hagfish from the present study may have several explanations. Compared to bony fishes Hagfish may have unusually efficient PAH excreting capability through alternative pathways, or PAH may be accumulated in the liver or other lipid rich organs. Under the given exposure conditions, this species may not have an efficient uptake of these compounds from the surrounding water. The former may be caused by the species ability to close the flow over the gills and for periods of time relying only on cutaneous respiration, an adaptation to its sediment burrowing behavior. Further investigations are necessary prior to formulating conclusions regarding the physiological explanation for these findings.

\subsection{Investigation towards identification of interfering compounds}

Differences in individual fluorescence profiles indicate that several unknown compounds interfering with the fluorescence readings are present in the bile samples at different concentrations (Figure 3). The fluorescence profiles with up to three major peaks also indicate that the compounds are highly conjugated. 
In an attempt to elucidate the structure of the unknown compounds resulting in the high fluorescence signal, one sample was subjected to GC-MS analysis utilizing full ion scan mode. By such means we detected two compounds not normally found in bile samples from fish, in the $\mathrm{C}_{1}-\mathrm{OH}-$ phenanthrene and $\mathrm{C}_{2}-\mathrm{OH}$-phenanthrene region of the $\mathrm{GC}$ chromatogram containing one bromine atom each $(\mathrm{m} / \mathrm{z}, 397 / 399$ and $\mathrm{m} / \mathrm{z}, 280 / 282$, respectively). The presence of bromine was confirmed by the typical isotope pattern $\left({ }^{79} \mathrm{Br}\right.$ and $\left.{ }^{81} \mathrm{Br}\right)$ and loss of $79 / 81 \mathrm{Da}$ in both spectra. It was also determined that both compounds contained one hydroxyl group due to the fact that both compounds showed loss of $73 \mathrm{Da}$ in the MS spectra, which was caused by the fragment $\mathrm{C}_{3} \mathrm{H}_{9} \mathrm{Si} \cdot(\mathrm{TMS} \cdot)$. The TMS group is derived from sample preparation where the bile sample post enzymatic digestion is treated with bis(trimethylsilyl)-trifluoroacetamide in order to convert all free hydroxyl groups to the corresponding TMS-ether (Beyer et al., 2010). These analyses did not provide sufficient information in order to elucidate the structure of these two compounds.

The present work could not determine if these compounds are naturally found in Atlantic hagfish or are metabolites of pollutants acquired from the environment. However, due to the fact that brominated flame retardants usually contain 4-10 bromine atoms, it is unlikely that these compounds originate from such a source. It is possible that the brominated compounds are formed in situ since it is documented that Atlantic hagfish possess the enzyme haloperoxidase (Shinnar et al., 2000; Shinnar et al., 2003; Bittner et al., 2007) that catalyses the post-translational bromination of tryptophan in cathelicidins (antimicrobial peptides).

The large variability among individuals in concentration of these compounds indicates that their presence may be related to biological status such as recent food availability, exposure to pathogens or reproduction status, rather than exposure to pollutants. Further work is required in order to reveal the structure of these compounds, their origin, and possibly function.

\section{Summary and conclusions}

This study showed a lack of correspondence between bile fluorescence levels, an indicator of oil exposure, and actual levels of PAH metabolites in bile from environmentally exposed hagfish (Myxine glutinosa). Due to possible interference from unknown compounds in the bile, care must be taken when interpreting bile fluorescence 
data in hagfish. Furthermore, caution should be exercised when interpreting the data from GC-MS analysis in the $\mathrm{C}_{1}-\mathrm{OH}$-phenanthrene and $\mathrm{C}_{2}-\mathrm{OH}$-phenanthrene region of GC chromatograms. Further work is required in order to determine the structure of the unknown compounds. Results demonstrate the importance of biomarker baseline investigations prior to use of new indicator species.

\section{Acknowledgements}

This study was funded by Eni Norge AS. Erik Bjørnbom is acknowledged for providing oil from the Goliat field. Total E\&P Norge AS is acknowledged for providing results from the additional laboratory exposure. The authors would like to thank Atle Nævdal, Kai-Erik Uleberg, Claudia Lucas and Solveig Apeland for technical assistance and Lundsvågen naturskole for providing hagfish from SW Norway. Constructive comments from the referees has been highly appreciated.

\section{References}

Aas, E., Beyer, J., Goksøyr, A., 1998. PAH in fish bile detected by fixed wavelength fluorescence. Marine Environmental Research 46, 225-228.

Aas, E., Klungsøyr, J., 1998. PAH metabolites in bile and EROD activity in North Sea fish. Marine Environmental Research 46, 229-232.

Aas, E., Beyer, J., Goksøyr, A., 2000. Fixed wavelength fluorescence (FF) of bile as a monitoring tool for polyaromatic hydrocarbon exposure in fish: an evaluation of compound specificity, inner filter effect and signal interpretation. Biomarkers 5, 923.

Aas, E., Beyer, J., Jonsson, G., Reichert, W. L., Andersen, O. K., 2001. Evidence of uptake, biotransformation and DNA binding of polyaromatic hydrocarbons in Atlantic cod and corkwing wrasse caught in the vicinity of an aluminium works. Marine Environmental Research 52, 213-229. 
Anderson, I. G., Haslewood, G. A. D., Cross, A. D., Tökés, L., 1967. New evidence for the structure of myxinol. Biochemical Journal 104, 1061-1063.

Anderson, I. G., Haslewood, G. A. D., 1969. Comparative studies of bile salts; 16deoxymyxinol, a second bile alcohol from hagfish. Biochemical Journal 112, 763765.

Andersson, T., Nilsson, E., 1989. Characterization of cytochrome P-450-dependent activities in hagfish, dogfish, perch and spectacle caiman. Comparative Biochemistry and Physiology Part B 94, 99-105.

Ariese, F., Beyer, J., Jonsson, G., Visa, C. P., Krahn, M. M., 2005. Review of analytical methods for determining metabolites of polycyclic aromatic compounds (PACs) in fish bile. ICES Techniques in Marine Environmental Sciences. International Council for the Exploration of the Sea, Copenhagen, Denmark No. 39.

Beyer, J., Aas, E., Borgenvik, H. K., Ravn, P., 1998. Bioavailability of PAH in effluent water from an aluminum works evaluated by transplant caging and biliary fluorescence measurements of Atlantic cod (Gadus morhua L.). Marine Environmental Research 46, 233-236.

Beyer, J., Jonsson, G., Porte, C., Krahn, M. M., Ariese, F. 2010. Analytical methods for determining metabolites of polycyclic aromatic hydrocarbon (PAH) pollutants in fish bile: A review. Environmental Toxicology and Pharmacology 30, 224-244.

Bittner, S., Scherzer, R., Harlev, E., 2007. The five bromotryptophans. Amino Acids 33, $19-42$.

Collete, B. B., and G. Klein-MacPhee (Editors). 2002. Bigelow and Schrodeder's Fishes of the Gulf of Maine. 3rd Edition. Smithsonian Institution Press, Washington, D.C.

Cross, A. D., 1966. Nuclear-magnetic-resonance and mass-spectral study of myxinol tetra-acetate. Biochemical Journal 100, 238-241.

Fudge, D. S., Levy, N., Chiu, S., Gosline, J. M., 2005. Composition, morphology and mechanics of hagfish slime. Journal of Experimental Biology 208, 4613-4625.

Furevik D.M. (1997) Development of a new cod pot and comparative trials with commercial pots and long-line. Paper presented to the ICES Working Group on Fishing Technology and Fish Behaviour, 14-17 April 1997, Hamburg, Germany. 
Hahn M.E., Woodin B.R., Stegeman J.J., Tillitt D.E., 1998. Aryl hydrocarbon receptor function in early vertebrates: Inducibility of cytochrome P450 1A in agnatan and elasmobranch fish. Comparative Biochemistry and Physiology Part C. 120: 67-75.

Hahn, M. E., 2002. Aryl hydrocarbon receptors: diversity and evolution. ChemicoBiological Interactions 141, 131-160.

Haslewood, G. A. D., 1966. Comparative studies of bile salts. Biochemical Journal 100, 233-237.

Haslewood, G. A. D., 1967. Bile salt evolution. Journal of Lipid Research 8, 535-550.

Hofmann, A. E., Hagey, L. R., 2008. Bile acids: Chemistry, pathochemistry, biology, pathobiology, and therapeutics. Cellular and Molecular Life Sciences 65, 24612483.

Insausti D., Carrasson M., Maynou F., Cartes J.E., Solé M. 2009. Biliary fluorescent aromatic compounds (FACs) measured by fixed wavelength fluorescence (FF) in several marine fish species from the NW Mediterranean. Marine Pollution Bulletin $58: 1635-1642$.

Jonsson, G., Beyer, J., Wells, D., Ariese, F., 2003. The application of HPLC-F and GCMS to the analysis of selected hydroxyl polycyclic hydrocarbons in two certified fish bile reference materials. Journal of Environmental Monitoring 5, 513-520.

Jonsson, G., Taban, I. C., Jørgensen, K. B., Sundt, R. C., 2004. Quantitative determination of de-conjugated chrysene metabolites in fish bile by HPLCfluorescence and GC-MS. Chemosphere 54, 1085-1097.

Krahn, M. M., Burrows, M. S., Malins, D. C., 1984. Determination of metabolites of xenobiotics in the bile of fish from polluted waterways. Xenobiotica 14, 633-646.

Krahn, M. M., Burrows, D. G., MacLeod, W. D., Jr., Malins, D. C., 1987. Determination of individual metabolites of aromatic compounds in hydrolyzed bile of English sole (Parophrys vetulus) from polluted sites in Puget Sound, Washington. Archives of Environmental Contamination and Toxicology 16, 511-522.

Lim, J., Fudge, D. S., Levy, N., Gosline, J. M., 2006. Hagfish slime ecomechanics: testing the gill-clogging hypothesis. Journal of Experimental Biology 209, 702-710. 
Lin, E. L. C., Cormier, S. M., Torsella, J. A., 1996. Fish biliary polycyclic aromatic hydrocarbons metabolites estimated by fixed-wavelength fluorescence: comparison with HPLC-fluorescent detection. Ecotoxicology and Environmental Safety 35, 1623.

Nicholls, H., 2009. Mouth to mouth. Nature 461, 164-166.

Sanni, S., Øysæd, K.B., Høivangli, V. and Gaudebert, B., 1998. A continuous flow system (CFS) for chronic exposure of aquatic organisms. Marine Environmental Research 46, 97-101.

Shinnar, A. E., Bautista, J., Fu, S., 2000. Bromotryptophan: Evidence for enzymatic bromination of tryptophan in hagfish intestinal antimicrobial peptides. FASEB Journal 14, A1488-A1488.

Shinnar, A. E., Butler, K. L., Park, H. J., 2003. Cathelicidin family of antimicrobial peptides: proteolytic processing and protease resistance. Bioorganic Chemistry 31, 425-436.

Subramanian, S., Ross, N. W., MacKinnon, S. L., 2009. Myxinidin, A novel antimicrobial peptide from the epidermal mucus of hagfish, Myxine glutinosa L. Marine Biotechnology 11, 748-757.

Uzzell, T., Stolzenberg, E. D., Shinner, A. E., Zasloff, M., 2003. Hagfish intestinal antimicrobial peptides are ancient cathelicidins. Peptides 24, 1655-1667.

van der Oost, R., Beyer, J., Vermeulen, N.P.E. 2003. Fish bioaccumulation and biomarkers in environmental risk assessment: a review. Environmental Toxicology and Pharmacology 2: 57-149. 
Figure legends:

Figure 1.

Sampling locations for Atlantic hagfish (Myxine glutinosa) and tusk (Brosme brosme, Barents Sea only).

Figure 2.

Fixed wavelength fluorescence (FF, given as pyrene equiv. $\mu \mathrm{g} / \mathrm{mL}$ bile) results for Atlantic hagfish and tusk from the Barents Sea, Atlantic hagfish from SW Norway (control fish from the exposure experiment), and Atlantic hagfish from SW Norway exposed to $0.25 \mathrm{ppm}$ crude oil.

Figure 3.

Synchronous fluorescence spectrometry (SFS) of bile samples of hagfish (Myxine glutinosa) and tusk (Brosme brosme), collected in the Southern Barents Sea, indicating the extent of the inter-individual differences in signal profiles. A difference of $42 \mathrm{~nm}$ between excitation and emission $(\Delta \lambda)$ was applied. Excitation wavelength typical for metabolites of 2, 4, and 5 ring PAHs are indicated (Aas et al., 2000).

Figure 4.

Average levels of bile fixed wavelength fluorescence (FF, given as pyrene equiv. $\mu \mathrm{g} / \mathrm{mL}$ bile) in tusk (Brosme brosme), Atlantic hagfish (Myxine glutinosa) from Southern Barents Sea, Atlantic hagfish from SW Norway (negative laboratory control), and Atlantic hagfish from SW Norway exposed to $0.25 \mathrm{ppm}$ crude oil. 
Table legends:

Table 1.

Bile PAH metabolites (ng/g) analyzed by GC-MS single ion mode (SIM): Results from Atlantic hagfish (Myxine glutinosa) collected in the Barents Sea, SW Norway and from exposure to $0.25 \mathrm{ppm}$ Goliat field crude oil). PAH metabolite levels in samples of halibut (Hippoglossus hippoglossus) from the same oil exposure is included for comparison. na $=$ not analyzed.

Table 2.

PAH concentrations in laboratory sea water supplemented with $0.25 \mathrm{ppm}$ Goliat field crude oil and concentration of the various compounds in crude oil from the Goliat field. Data express mean values ( $\mu \mathrm{g} / \mathrm{L}$ seawater) of two independent GC-MS analyses conducted on water samples taken on day 5 of the experiment. Quantification limit (LOQ) for single compounds $0,005 \mathrm{~g} / \mathrm{L} . \mathrm{nd}=$ not detected; * = compound below the quantification limit (values in brackets are approximate concentrations). Levels of all 5 and 6 ringed PAHs included in the analysis were found to be below LOQ. 
Fig. 1

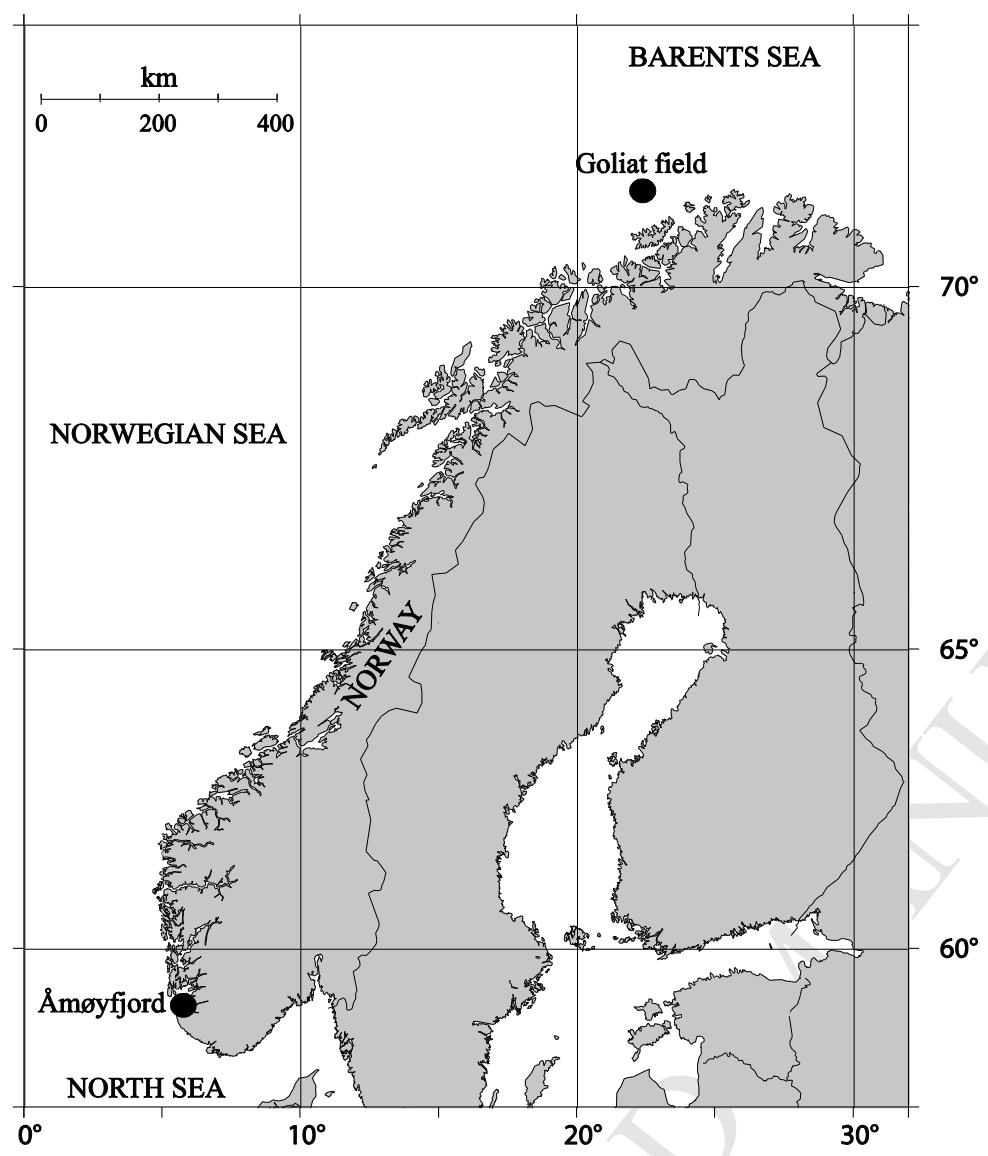


Fig. 2

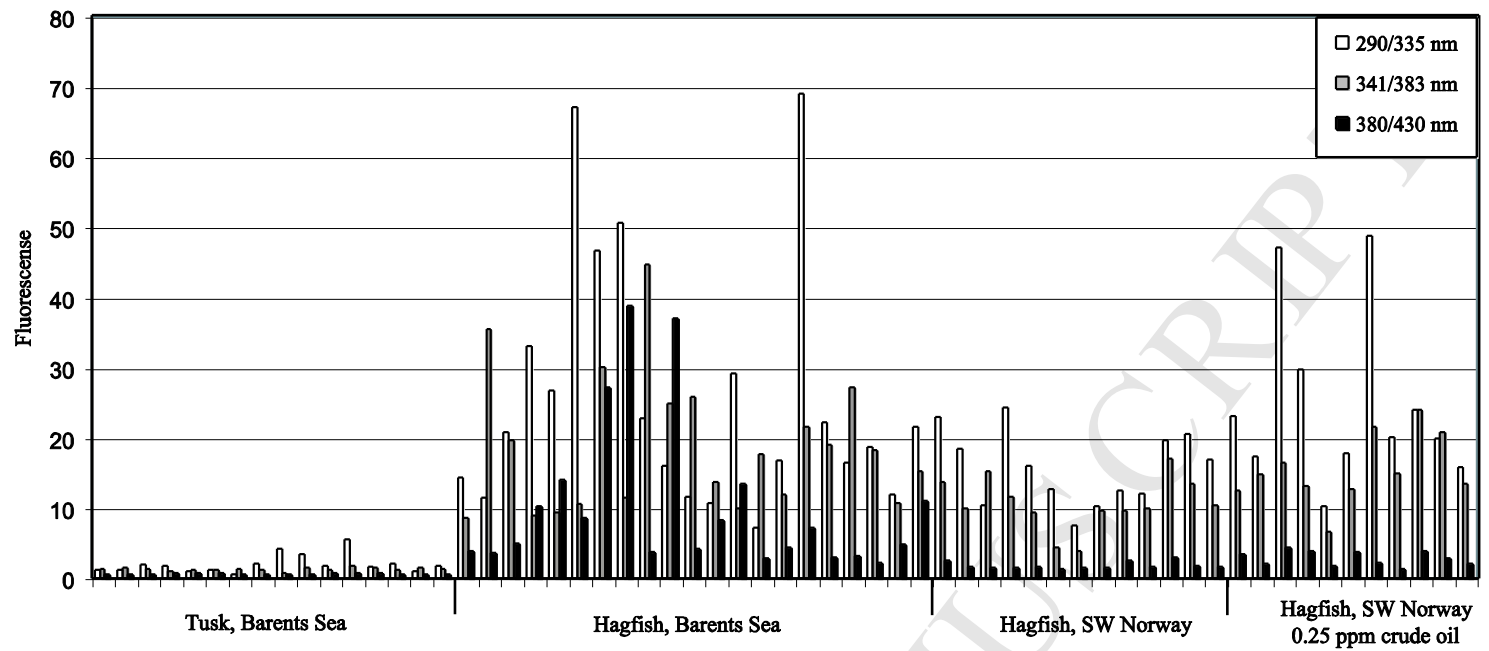

Fig. 3

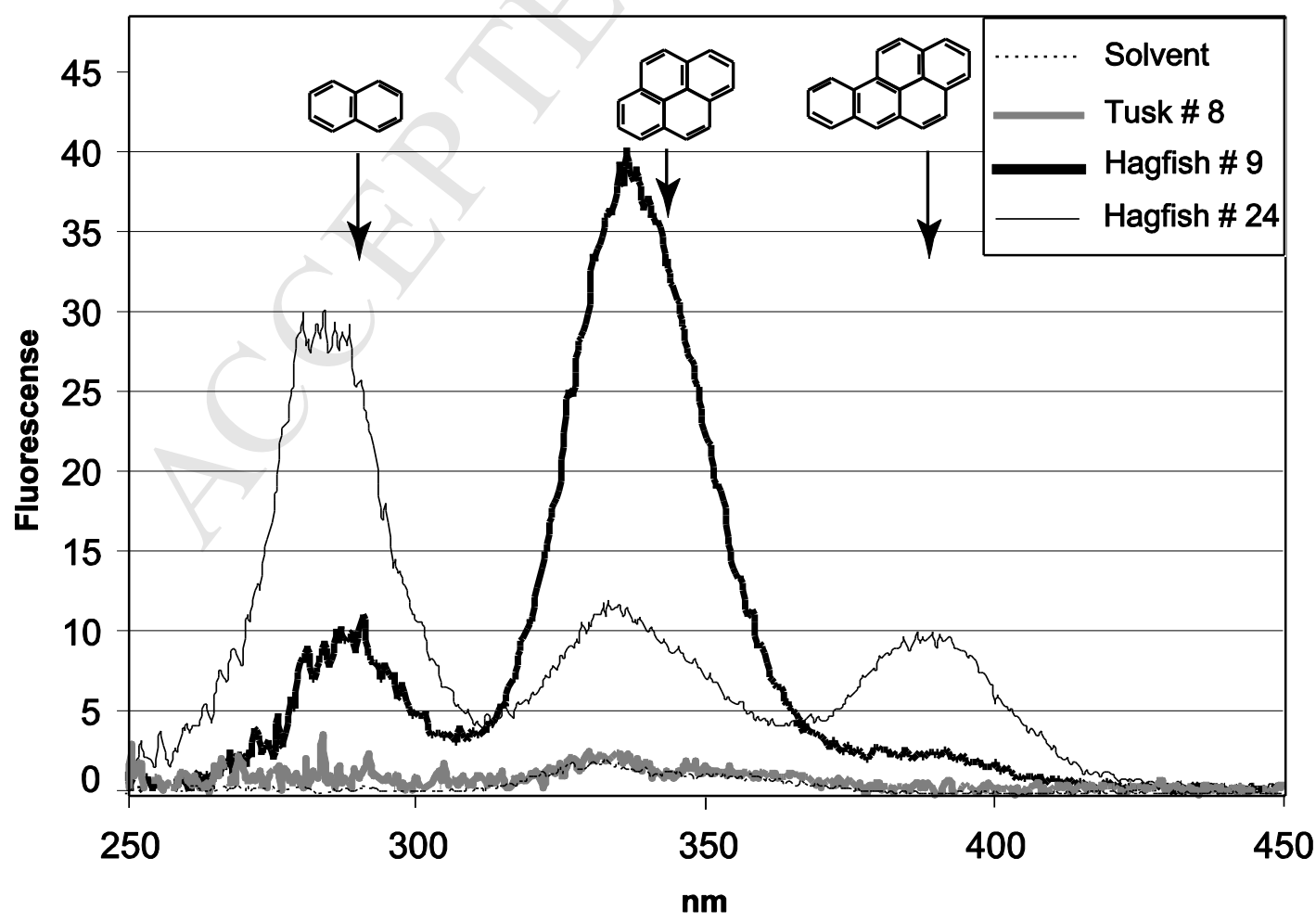


Fig.4

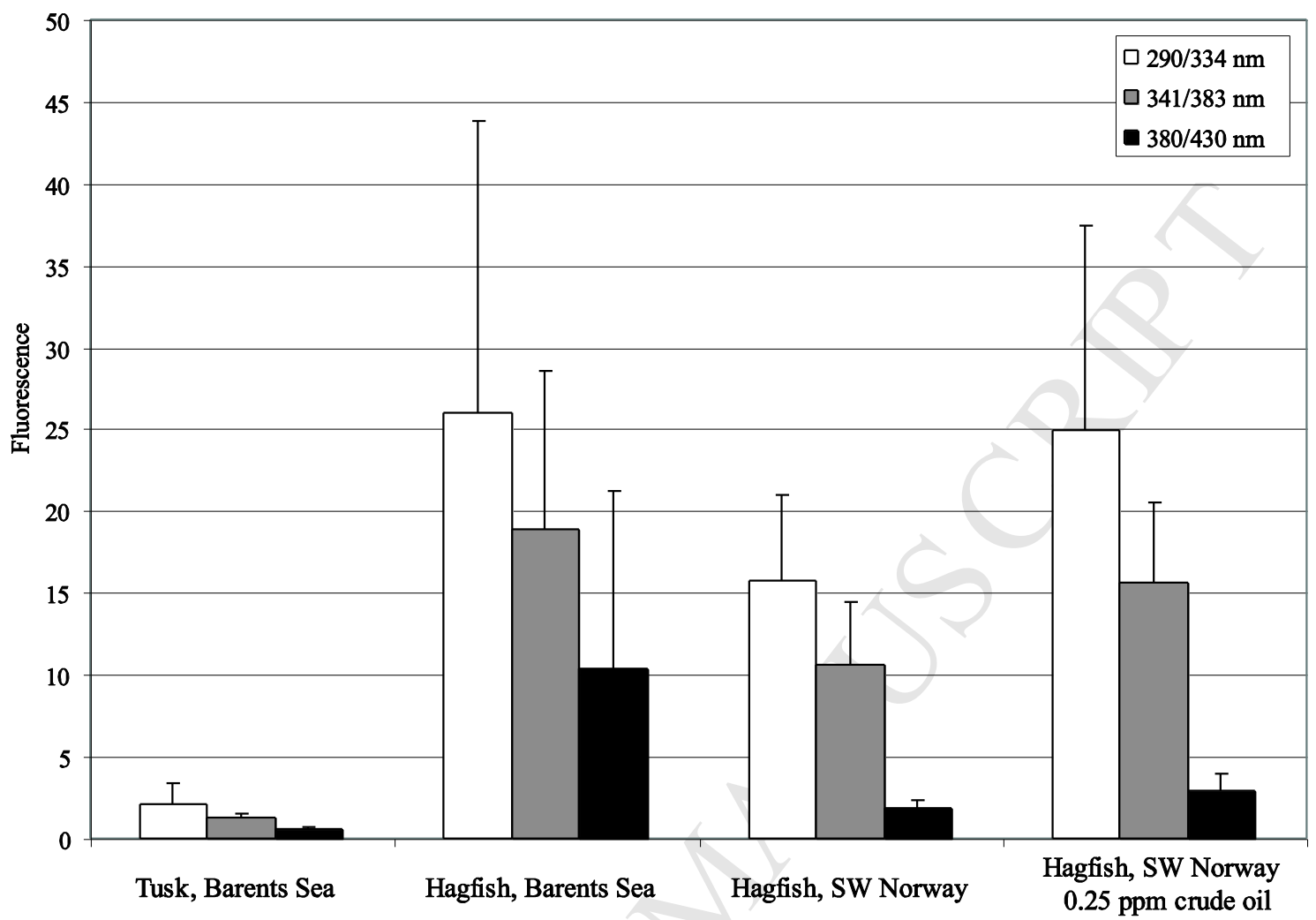


Table 1

\begin{tabular}{|c|c|c|c|c|c|c|c|c|c|c|c|c|c|c|c|c|c|c|c|c|c|c|c|c|c|c|}
\hline \multirow[b]{2}{*}{ Sample \# } & & \multicolumn{10}{|c|}{$\begin{array}{l}\text { Hagfish, Barents Sea } \\
\text { field samples }\end{array}$} & \multicolumn{7}{|c|}{$\begin{array}{c}\text { Hagfish, SW Norway } \\
\text { laboratory control }\end{array}$} & \multicolumn{5}{|c|}{$\begin{array}{c}\text { Hagfish, SW Norway } \\
0.25 \mathrm{ppm} \text { crude oil }\end{array}$} & \multicolumn{3}{|c|}{$\begin{array}{l}\text { Halibut (farmed) } \\
0.25 \mathrm{ppm} \text { crude oil }\end{array}$} \\
\hline & & 9 & 11 & 14 & 16 & 18 & 19 & 20 & 22 & 27 & 30 & 1 & 2 & 5 & 6 & 10 & 11 & 12 & 1 & 3 & 6 & 7 & 8 & 1 & 2 & 3 \\
\hline PAH-matabolite (ng/g) & LOQ & & & & & & & & & & & & & & & & & & & & & & & & & \\
\hline 1-OH-naphthalene & 30 & $<*$ & 88 & $<*$ & $<*$ & $<*$ & $<*$ & $<*$ & 59 & 63 & 42 & $<*$ & $<*$ & $<*$ & $<*$ & $<*$ & $<*$ & $<*$ & $<*$ & $<*$ & $<*$ & $<*$ & $<*$ & $<*$ & $<*$ & $<*$ \\
\hline 2-OH-naphthalene & 30 & 217 & 155 & 261 & 333 & $<*$ & 718 & $<*$ & $<*$ & 247 & 704 & 322 & 51 & 139 & 64 & 155 & 601 & 69 & 188 & 79 & 194 & 212 & 33 & $<*$ & $<*$ & $<*$ \\
\hline $\mathrm{C}_{1}$-OH-naphthalene & 300 & 536 & $<*$ & $<*$ & 442 & 655 & 558 & 557 & 612 & 442 & 1085 & 551 & 417 & $<*$ & 425 & $<*$ & 865 & 321 & 732 & 370 & 453 & $<*$ & $<*$ & 2441 & 757 & 1654 \\
\hline $\mathrm{C}_{2}$-OH-naphthalene & 500 & $<*$ & $<*$ & $<*$ & $<*$ & $<*$ & 609 & $<*$ & $<*$ & $<*$ & $<*$ & $<*$ & $<*$ & $<*$ & $<*$ & $<*$ & $<*$ & $<*$ & $<*$ & $<*$ & $<*$ & $<*$ & $<*$ & 17603 & 4796 & 10381 \\
\hline $\mathrm{C}_{3}$-OH-naphthalene & 1000 & $<*$ & $<*$ & 1062 & $<*$ & $<*$ & 1930 & $<*$ & $<*$ & $<*$ & 2071 & $<*$ & $<*$ & $<*$ & $<*$ & $<*$ & $<*$ & $<*$ & $<*$ & $<*$ & $<*$ & $<*$ & $<*$ & 36067 & 10282 & 26675 \\
\hline 1-OH-phenanthrene & 30 & $<*$ & $<*$ & $<*$ & $<*$ & $<*$ & 534 & 34 & 32 & na & 74 & $<*$ & $<*$ & $<*$ & $<*$ & $<*$ & $<*$ & $<*$ & $<*$ & $<*$ & $<*$ & $<*$ & $<*$ & 316 & 132 & 193 \\
\hline 1-OH-pyrene & 30 & $<*$ & $<*$ & $<*$ & $<*$ & $<*$ & na & $<*$ & $<*$ & na & $<*$ & 133 & 100 & 116 & 169 & 113 & 332 & 97 & 126 & 241 & 318 & 160 & 88 & 1118 & 370 & 898 \\
\hline
\end{tabular}


Table 2

\begin{tabular}{|c|l|c|c|c|}
\hline PAH group & \multicolumn{1}{|c|}{ Compound } & Goliat crude oil & Control & $0.25 \mathrm{ppm}$ oil \\
\hline 2-Ring PAHs & Naphthalene & $1030 \mathrm{mg} / \mathrm{kg}$ & $*(0.002 \mu \mathrm{g} / \mathrm{L})$ & $0.190 \mu \mathrm{g} / \mathrm{L}$ \\
\hline & $\mathrm{C}_{1}$-naphthalene & $2700 \mathrm{mg} / \mathrm{kg}$ & $*(0.002 \mu \mathrm{g} / \mathrm{L})$ & $0.541 \mu \mathrm{g} / \mathrm{L}$ \\
\hline & $\mathrm{C}_{2}$-naphthalene & $4200 \mathrm{mg} / \mathrm{kg}$ & $*(0.002 \mu \mathrm{g} / \mathrm{L})$ & $0.808 \mu \mathrm{g} / \mathrm{L}$ \\
\hline & $\mathrm{C}_{3}$-naphthalene & $2800 \mathrm{mg} / \mathrm{kg}$ & $*$ & $0.479 \mu \mathrm{g} / \mathrm{L}$ \\
\hline 3-Ring PAHs & Acenaphthylene & $*$ & $\mathrm{nd}$ & $*$ \\
\hline & Acenaphthene & $*(12 \mathrm{mg} / \mathrm{kg})$ & $\mathrm{nd}$ & $*$ \\
\hline & Fluorene & $75 \mathrm{mg} / \mathrm{kg}$ & $\mathrm{nd}$ & $0.011 \mu \mathrm{g} / \mathrm{L}$ \\
\hline & Phenanthrene & $175 \mathrm{mg} / \mathrm{kg}$ & $\mathrm{nd}$ & $0.028 \mu \mathrm{g} / \mathrm{L}$ \\
\hline & Anthracene & $*$ & $\mathrm{nd}$ & $\mathrm{nd}$ \\
\hline & $\mathrm{C}_{1}$-phen./anthr. & $280 \mathrm{mg} / \mathrm{kg}$ & $\mathrm{nd}$ & $0.037 \mu \mathrm{g} / \mathrm{L}$ \\
\hline & $\mathrm{C}_{2}$-phen./anthr. & $310 \mathrm{mg} / \mathrm{kg}$ & $\mathrm{nd}$ & $0.039 \mu \mathrm{g} / \mathrm{L}$ \\
\hline DBTs & Dibenzothiophene & $27 \mathrm{mg} / \mathrm{kg}$ & $\mathrm{nd}$ & $*(0.004 \mu \mathrm{g} / \mathrm{L})$ \\
\hline & $\mathrm{C}_{1}$-dibenzothiophene & $73 \mathrm{mg} / \mathrm{kg}$ & $\mathrm{nd}$ & $0.010 \mu \mathrm{g} / \mathrm{L}$ \\
\hline & $\mathrm{C}_{2}$-dibenzothiophene & $74 \mathrm{mg} / \mathrm{kg}$ & $\mathrm{nd}$ & $0.006 \mu \mathrm{g} / \mathrm{L}$ \\
\hline 4-Ring PAHs & Fluoranthene & $*(6 \mathrm{mg} / \mathrm{kg})$ & $\mathrm{nd}$ & $*$ \\
\hline & Pyrene & $*$ & $\mathrm{nd}$ & $*$ \\
\hline
\end{tabular}




\begin{tabular}{|c|c|c|c|c|c|c|c|c|c|c|c|c|c|c|c|c|c|c|c|c|c|c|c|c|c|c|}
\hline \multirow[b]{2}{*}{ Sample \# } & & \multicolumn{10}{|c|}{$\begin{array}{l}\text { Hagfish, Barents Sea } \\
\text { field samples }\end{array}$} & \multicolumn{7}{|c|}{$\begin{array}{l}\text { Hagfish, SW Norway } \\
\text { laboratory control }\end{array}$} & \multicolumn{5}{|c|}{$\begin{array}{l}\text { Hagfish, SW Norway } \\
0.25 \text { ppm crude oil }\end{array}$} & \multicolumn{3}{|c|}{$\begin{array}{c}\text { Halibut (farmed) } \\
0.25 \text { ppm crude oil }\end{array}$} \\
\hline & & 9 & 11 & 14 & 16 & 18 & 19 & 20 & 22 & 27 & 30 & 1 & 2 & 5 & 6 & 10 & 11 & 12 & 1 & 3 & 6 & 7 & 8 & 1 & 2 & 3 \\
\hline PAH-matabolite (ng/g) & LOQ & & & & & & & & & & & & & & & & & & & & & & & & & \\
\hline 1-OH-naphthalene & 30 & $<*$ & 88 & $<*$ & $<*$ & $<*$ & $<*$ & $<*$ & 59 & 63 & 42 & $<*$ & $<*$ & $<*$ & $<*$ & $<*$ & $<*$ & $<*$ & $<*$ & $<*$ & $<*$ & $<*$ & $<*$ & $<*$ & $<*$ & $<*$ \\
\hline 2-OH-naphthalene & 30 & 217 & 155 & 261 & 333 & $<*$ & 718 & $<*$ & $<*$ & 247 & 704 & 322 & 51 & 139 & 64 & 155 & 601 & 69 & 188 & 79 & 194 & 212 & 33 & $<*$ & $<*$ & $<*$ \\
\hline $\mathrm{C}_{1}$-OH-naphthalene & 300 & 536 & $<*$ & $<*$ & 442 & 655 & 558 & 557 & 612 & 442 & 1085 & 551 & 417 & $<*$ & 425 & $<*$ & 865 & 321 & 732 & 370 & 453 & $<*$ & $<*$ & 2441 & 757 & 1654 \\
\hline $\mathrm{C}_{2}$-OH-naphthalene & 500 & $<*$ & $<*$ & $<*$ & $<*$ & $<*$ & 609 & $<*$ & $<*$ & $<*$ & $<*$ & $<*$ & $<*$ & $<*$ & $<*$ & $<*$ & $<*$ & $<*$ & $<*$ & $<*$ & $<*$ & $<*$ & $<*$ & 17603 & 4796 & 10381 \\
\hline $\mathrm{C}_{3}$-OH-naphthalene & 1000 & $<*$ & $<*$ & 1062 & $<*$ & $<*$ & 1930 & $<*$ & $<*$ & $<*$ & 2071 & $<*$ & $<*$ & $<*$ & $<*$ & $<*$ & $<*$ & $<*$ & $<*$ & $<*$ & $<*$ & $<*$ & $<*$ & 36067 & 10282 & 26675 \\
\hline 1-OH-phenanthrene & 30 & $<*$ & $<*$ & $<*$ & $<*$ & $<*$ & 534 & 34 & 32 & na & 74 & $<*$ & $<*$ & $<*$ & $<*$ & $<*$ & $<*$ & $<*$ & $<*$ & $<*$ & $<*$ & $<*$ & $<*$ & 316 & 132 & 193 \\
\hline 1-OH-pyrene & 30 & $<*$ & $<*$ & $<*$ & $<*$ & $<*$ & na & $<*$ & $<*$ & na & $<*$ & 133 & 100 & 116 & 169 & 113 & 332 & 97 & 126 & 241 & 318 & 160 & 88 & 1118 & 370 & 898 \\
\hline
\end{tabular}


ACCEPTED MANUSCRIPT

\begin{tabular}{|c|c|c|c|c|}
\hline PAH group & Compound & Goliat crude oil & Control & $0.25 \mathrm{ppm}$ oil \\
\hline \multirow[t]{4}{*}{ 2-Ring PAHs } & Naphthalene & $1030 \mathrm{mg} / \mathrm{kg}$ & $*(0.002 \mu \mathrm{g} / \mathrm{L})$ & $0.190 \mu \mathrm{g} / \mathrm{L}$ \\
\hline & $\mathrm{C}_{1}$-naphthalene & $2700 \mathrm{mg} / \mathrm{kg}$ & $*(0.002 \mu \mathrm{g} / \mathrm{L})$ & $0.541 \mu \mathrm{g} / \mathrm{L}$ \\
\hline & $\mathrm{C}_{2}$-naphthalene & $4200 \mathrm{mg} / \mathrm{kg}$ & $*(0.002 \mu \mathrm{g} / \mathrm{L})$ & $0.808 \mu \mathrm{g} / \mathrm{L}$ \\
\hline & $\mathrm{C}_{3}$-naphthalene & $2800 \mathrm{mg} / \mathrm{kg}$ & $*$ & $0.479 \mu \mathrm{g} / \mathrm{L}$ \\
\hline \multirow[t]{7}{*}{ 3-Ring PAHs } & Acenaphthylene & $*$ & nd & $*$ \\
\hline & Acenaphthene & $*(12 \mathrm{mg} / \mathrm{kg})$ & nd & $*$ \\
\hline & Fluorene & $75 \mathrm{mg} / \mathrm{kg}$ & nd & $0.011 \mu \mathrm{g} / \mathrm{L}$ \\
\hline & Phenanthrene & $175 \mathrm{mg} / \mathrm{kg}$ & nd & $0.028 \mu \mathrm{g} / \mathrm{L}$ \\
\hline & Anthracene & $*$ & nd & nd \\
\hline & $\mathrm{C}_{1}$-phen./anthr. & $280 \mathrm{mg} / \mathrm{kg}$ & nd & $0.037 \mu \mathrm{g} / \mathrm{L}$ \\
\hline & $\mathrm{C}_{2}$-phen./anthr. & $310 \mathrm{mg} / \mathrm{kg}$ & nd & $0.039 \mu \mathrm{g} / \mathrm{L}$ \\
\hline \multirow[t]{3}{*}{ DBTs } & Dibenzothiophene & $27 \mathrm{mg} / \mathrm{kg}$ & nd & $*(0.004 \mu \mathrm{g} / \mathrm{L})$ \\
\hline & $\mathrm{C}_{1}$-dibenzothiophene & $73 \mathrm{mg} / \mathrm{kg}$ & nd & $0.010 \mu \mathrm{g} / \mathrm{L}$ \\
\hline & $\mathrm{C}_{2}$-dibenzothiophene & $74 \mathrm{mg} / \mathrm{kg}$ & nd & $0.006 \mu \mathrm{g} / \mathrm{L}$ \\
\hline \multirow[t]{2}{*}{ 4-Ring PAHs } & Fluoranthene & $*(6 \mathrm{mg} / \mathrm{kg})$ & nd & $*$ \\
\hline & Pyrene & $*$ & nd & * \\
\hline
\end{tabular}




\section{Figure}

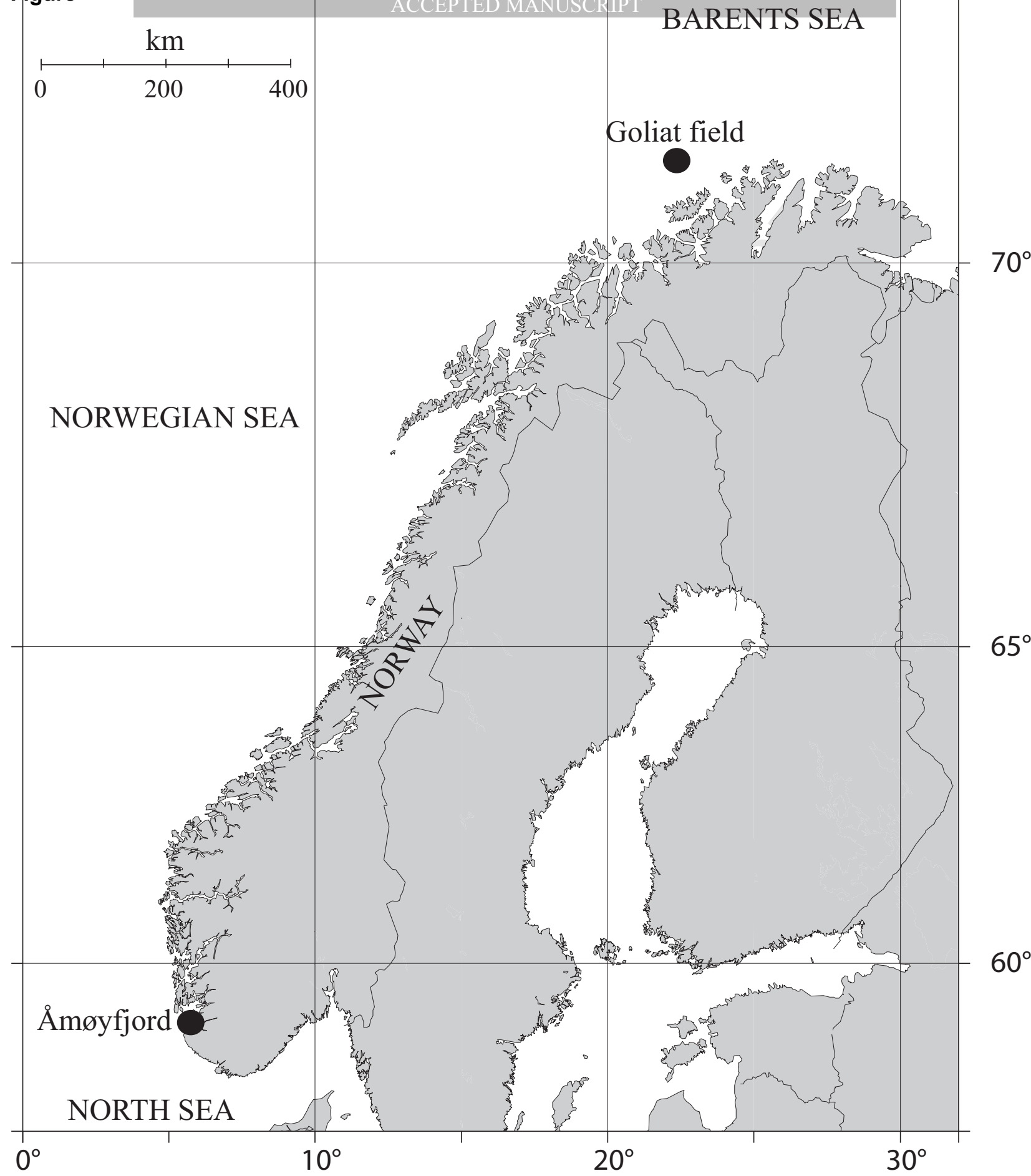


$\square 341 / 383 \mathrm{~nm}$

— $380 / 430 \mathrm{~nm}$

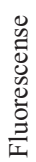

70

60
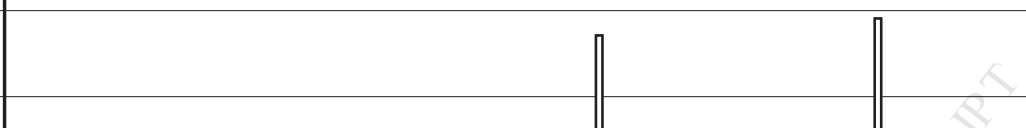

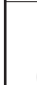

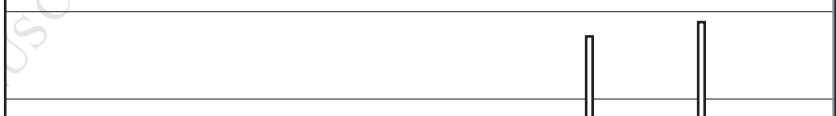

10

0

Tusk, Barents Sea

Hagfish, Barents Sea

Hagfish, SW Norway
Hagfish, SW Norway

0.25 ppm crude oil 


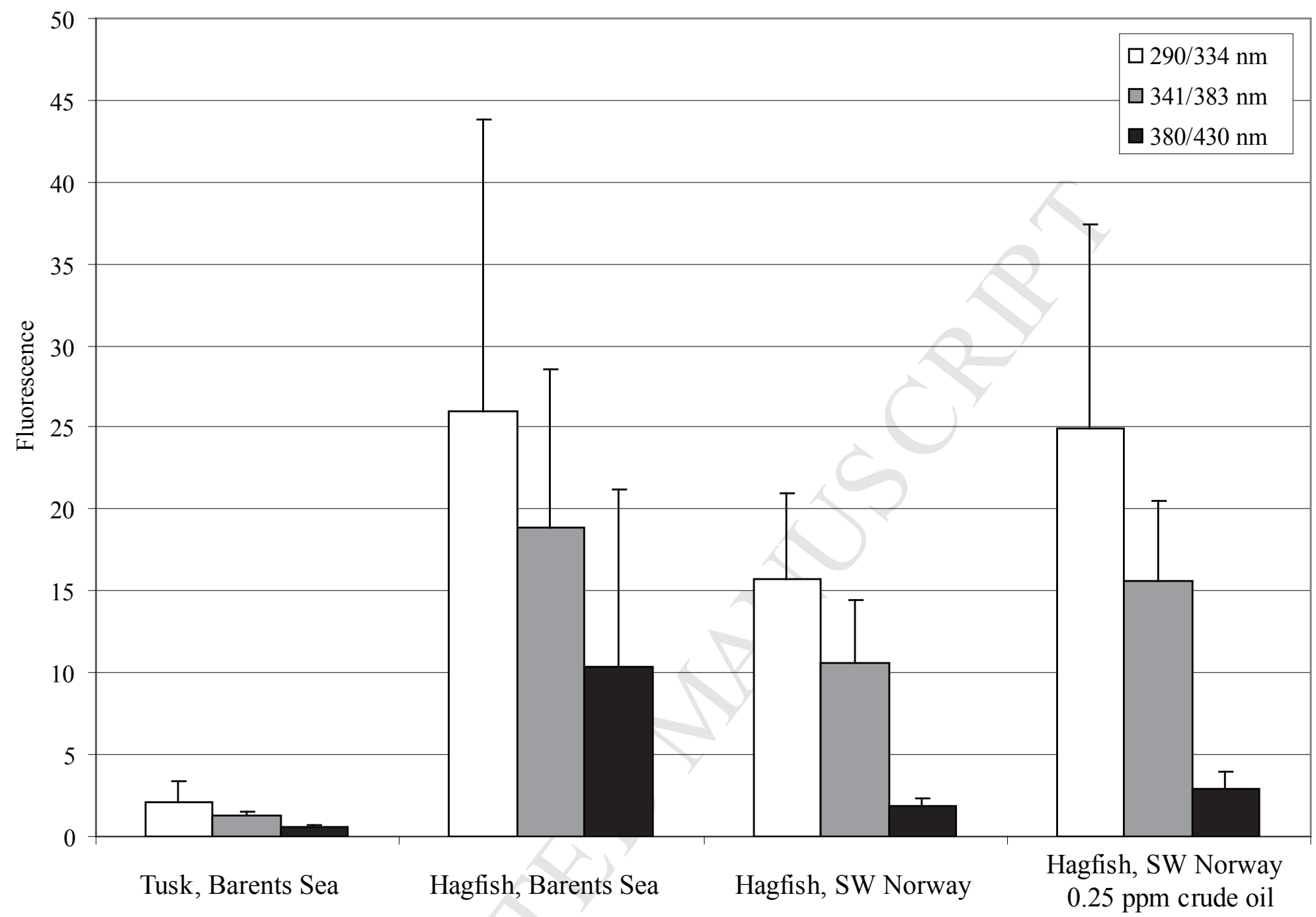

